\title{
Peptide foldamers composed of six-membered ring $\alpha, \alpha$-disubstituted $\alpha$-amino acids with two changeable chiral acetal moieties
}

Kazuhiro Tanda, ${ }^{\mathrm{a}, \dagger}$ Ryo Eto, ${ }^{\mathrm{b}}$ Kazuya Kato, ${ }^{\mathrm{b}}$ Makoto Oba, ${ }^{\mathrm{b}}$ Atsushi Ueda, ${ }^{\mathrm{b}}$ Hiroshi Suemune, ${ }^{\mathrm{a}}$ Mitsunobu Doi, ${ }^{\mathrm{c}}$ Yosuke Demizu, ${ }^{\mathrm{d}}$ Masaaki Kurihara, ${ }^{\mathrm{d}}$ and Masakazu Tanaka ${ }^{\mathrm{b}}$

${ }^{a}$ Graduate School of Pharmaceutical Sciences, Kyushu University, Fukuoka 812-8582, Japan

${ }^{b}$ Graduate School of Biomedical Sciences, Nagasaki University, 1-14 Bunkyo-machi, Nagasaki 852-8521, Japan

${ }^{c}$ Osaka University of Pharmaceutical Sciences, Osaka 569-1094, Japan

${ }^{d}$ Division of Organic Chemistry, National Institute of Health Sciences, Tokyo 158-8501, Japan

${ }^{\dagger}$ Present Address: Kyushu University of Health and Welfare, Nobeoka-shi, Miyazaki 882-8508

\section{ARTICLE INFO}

\section{Article history:}

Received

Received in revised form

Accepted

Available online

\section{Keywords:}

\section{conformation}

peptides

helix

$\alpha, \alpha$-disubstituted $\alpha$-amino acid

foldamer

\section{ABSTRACT}

Type your Abstract text here

2009 Elsevier Ltd. All rights reserved.

Chiral cyclic $\alpha, \alpha$-disubstituted $\alpha$-amino acids with four chiral centers at their acetal moieties were synthesized. An X-ray crystallographic analysis of homo-chiral tripeptide with $(2 R, 3 R)$ butane-2,3-diol acetal moieties revealed that the tripeptide formed both $(P)$ and $(M)$ helical structures, and all peptide main-chain $\mathrm{N}(i)-\mathrm{H}$ were intramolecularly hydrogen-bonded with the side-chain acetal $-\mathrm{O}-$ of the same amino acid residues $(i)$. The effect of the four chiral centers in the amino acid residue on the peptide backbone helical-screw control was very weak.

* Corresponding author. Tel/fax: +81 95819 2423; e-mail: matanaka@nagasaki-u.ac.jp 


\section{Introduction}

Conformational freedom-restricted oligopeptides have attracted the attention of organic, peptide, and medicinal chemists because they are capable of developing peptide organo-catalysts for asymmetric reactions and are also drug candidates derived from biologically active natural peptides. ${ }^{1} \alpha, \alpha$-Disubstituted $\alpha$ amino acids (dAAs) have been used to restrict the conformational freedom of their peptides. ${ }^{2}$ Oligopeptides incorporating $\alpha$ aminoisobutyric acid (Aib; $\alpha$ MeAla) have been shown to preferentially form $310^{-} / \alpha$-helical structures, whereas peptides having $\alpha$-ethylated dAAs, such as diethylglycine and $(S)$ butylethylglycine, are more likely to assume fully planar conformations. ${ }^{3}$ Differences in secondary structures (helix and planar conformations) are determined by the peptide-backbone torsion angles $\phi\left(\mathrm{C}^{\prime}-\mathrm{N}-\mathrm{C}_{\alpha}-\mathrm{C}^{\prime}\right)$ and $\psi\left(\mathrm{N}-\mathrm{C}_{\alpha}-\mathrm{C}^{\prime}-\mathrm{N}\right)$. For example, the ideal right-handed $(P) 3_{10^{-}}$-helix has $\phi-60^{\circ}$ and $\psi-30^{\circ}$ torsion angles, the right-handed $(P) \alpha$-helix has $\phi-57^{\circ}$ and $\psi-47^{\circ}$, and the fully planar conformation has $\phi 180^{\circ}$ and $\psi$ $180^{\circ}$. The patterns of intramolecular hydrogen bonds also differ in these secondary structures. For example, the $3_{10}$-helix forms an intramolecular hydrogen bond of the $\mathrm{N}(i+3)-\mathrm{H} \cdots \mathrm{O}(i)=\mathrm{C}(i)$ $i \leftarrow i+3$ type, whereas the $\alpha$-helix forms an intramolecular hydrogen bond of the $\mathrm{N}(i+4)-\mathrm{H} \cdots \mathrm{O}(i)=\mathrm{C}(i) \quad i \leftarrow i+4$ type. Moreover, the fully planar conformation forms an intramolecular hydrogen bond of the $\mathrm{C}_{5}$-conformation $\mathrm{N}(i)-\mathrm{H} \cdots \mathrm{O}(i)=\mathrm{C}(i) \quad i \leftarrow i$ type. By selecting appropriate dAAs, these secondary structures are partially controlled. However, the preferential conformations of known dAAs are limited to those of helix and planar conformations. Thus, the development of new dAAs with different conformational preferences is greatly desired.

One such dAA may be the achiral $O, O$-isopropylidene- $\alpha$ hydroxymethylserine $\{\mathrm{Hms}(\mathrm{Ipr})\}$ reported by Toniolo, Leplawy, and co-workers. ${ }^{4} \mathrm{Hms}(\mathrm{Ipr})$ peptides formed destabilized $33_{10^{-}}$ helical structures, in which hydrogen bonds were detected between peptide main-chain $\mathrm{NH}$ and side-chain acetonide - $\mathrm{O}-$.

We recently synthesized six-membered ring dAAs with a changeable chiral acetal moiety as well as the preferred secondary structures of their peptides. ${ }^{5}$ These findings prompted us to change the position of the acetal moiety on the cyclohexane ring and increase the number of acetal moieties on the cyclic amino acid. We designed six-membered ring dAAs with two chiral acetal moieties $\left\{(R, R)-\mathrm{Ac}_{6} \mathrm{c}^{35 \mathrm{dBu}},(R, R)-\mathrm{Ac}_{6} \mathrm{c}^{35 \mathrm{dPen}},(R, R)\right.$ $\left.\mathrm{Ac}_{6} \mathrm{c}^{35 \mathrm{dCyc}}\right\}$ (Figure 1). We speculated that, by increasing the number of chiral acetal moieties, with four chiral centers existing in one dAA residue, peptides having chiral dAAs may prefer to form a one-handed helical-screw structure. Furthermore, by transferring the acetal moiety from the $\delta$ position to the $\gamma$ position of cyclohexane, peptides with chiral dAAs may prefer to form intramolecular hydrogen bonds between peptide main-chain $\mathrm{NH}-$ and side-chain acetal -O-; therefore, the preferred conformation may not be $31^{-}$and $\alpha$-helices, but new secondary structures.
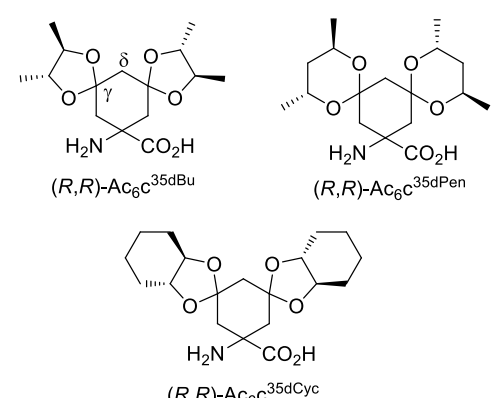

$(R, R)-\mathrm{Ac}_{6} \mathrm{C}^{35 \mathrm{dCyc}}$
Fig. 1. Six-membered ring dAAs with two chiral acetal moieties.

\section{Results and Discussion}

\subsection{Synthesis of six-membered ring $\alpha, \alpha$-disubstituted amino acids with two chiral acetal moieties.}

We synthesized cyclic dAAs with two acetal moieties, as follows (Scheme 1). Dimethyl malonate was alkylated with bromoacetone and then with methyl bromoacetate to produce a dialkylated product 1 in $67 \%$ yield. The intramolecular condensation of $\mathbf{1}$ with $\mathrm{NaH}$ in DMF gave a 3,5diketocyclohexane $\mathbf{2}$ in $89 \%$ yield. The acetalization of $\mathbf{2}$ with (2R,3R)-butane-2,3-diol afforded a diester 3a with chiral diacetal moieties in $97 \%$ yield. The mono-hydrolysis of diester 3a, followed by Curtius rearrangement with diphenylphosphoryl azide (DPPA) and workup with $\mathrm{BnOH}$ produced a six-membered ring dAA with two acetal moieties Cbz- $\left\{(R, R)-\mathrm{Ac}_{6} \mathrm{c}^{35 \mathrm{dBu}}\right\}-\mathrm{OMe}$ 4a in $68 \%$ yield. The amino acid $4 \mathbf{a}$ had four chiral centers at the side chain, but not at the $\alpha$-carbon atom.

The acetalization of $\mathbf{2}$ with $(2 R, 4 R)$-pentane-2,4-diol, followed by hydrolysis and Curtius rearrangement gave a cyclic dAA with two $(2 R, 4 R)$-pentane-2,4-diol acetal moieties $\mathbf{4 b}$, while that with $(R, R)$-cyclohexane-1,2-diol afforded 4c having two corresponding acetal moieties, respectively. Furthermore, the exchange of the butane-2,3-diol acetal moiety in $4 \mathbf{a}$ with cyclohexane-1,2-diol to produce $\mathbf{4 c}$ was completed in $38 \%$ yield by a treatment with excess diol (10 equiv) in the presence of $p$ $\mathrm{TsOH}$ in refluxing benzene.

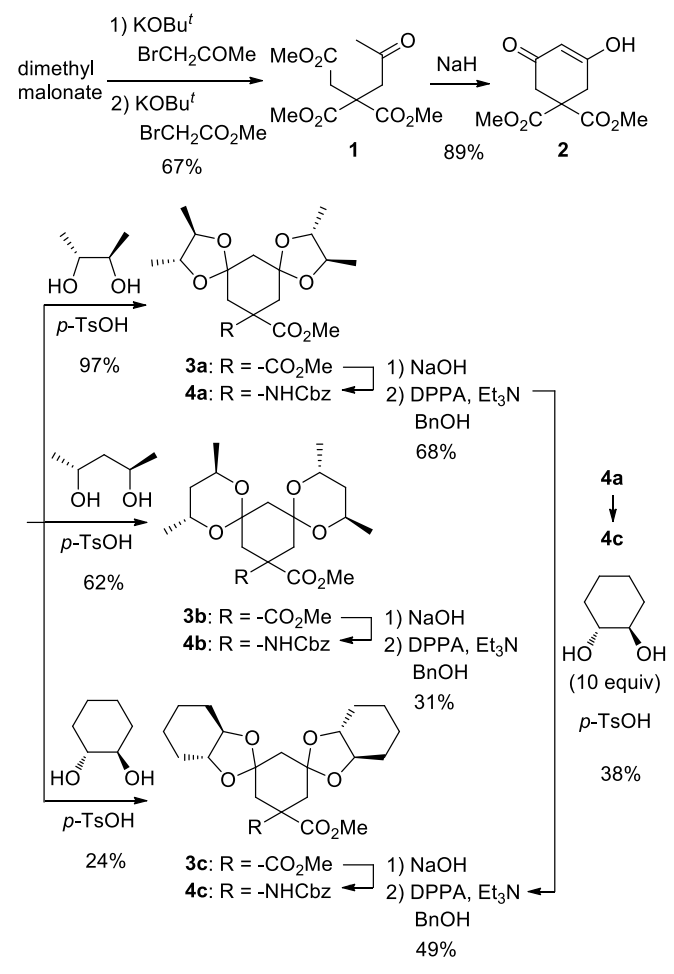


Scheme 1. Synthesis of cyclic dAAs with two chiral acetal moieties.

\subsection{Preparation of $(R, R)-\mathrm{Ac}_{6} \mathrm{c}^{35 \mathrm{dBu}}$ homopeptides.}

The C-terminal free amino acid $\mathbf{5}$ was prepared from $\mathbf{4 a}$ by alkaline hydrolysis and used without purification, and the $\mathrm{N}$ terminal free amino acid $\mathbf{6}$ was prepared from $\mathbf{4 a}$ in $93 \%$ yield by hydrogenolysis. The formation of peptide bond between $\mathbf{5}$ and $\mathbf{6}$ using 1-[bis(dimethylamino)methylene]- $1 H$-benzotriazolium 3oxide hexafluorophosphate (HBTU) as a coupling reagent produced the dipeptide 7 in $66 \%$ yield. Elongation of the peptide chain by fragment coupling or the step-wise addition of one amino acid from the $\mathrm{C}$-terminus to the $\mathrm{N}$-terminus did not proceed well. However, the elongation of peptides from the opposite $\mathrm{N}$-terminus to $\mathrm{C}$-terminus worked in solution phase methods using HBTU/1-hydroxybenzotriazole (HOBt) or $O$-(7azabenzotriazol-1-yl)-1,1,3,3-tetramethyluronium

hexafluorophosphate (HATU)/1-hydroxy-7-azabenzotriazole (HOAt) as coupling reagents, as shown in Scheme 2.
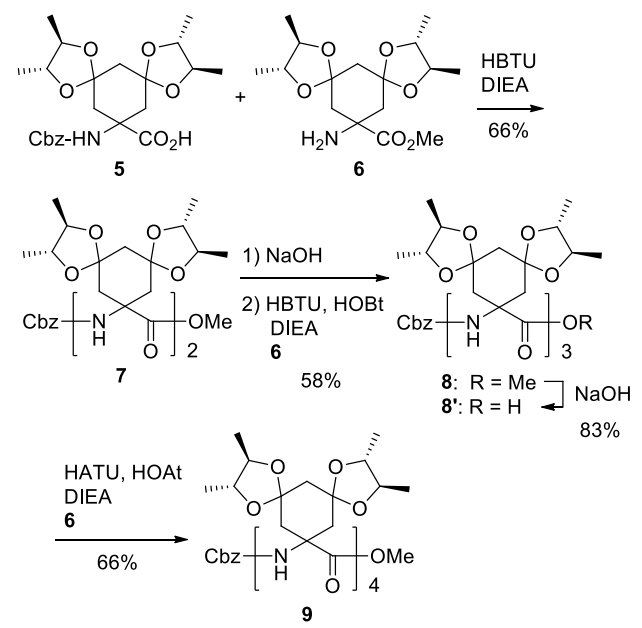

Scheme 2. Preparation of $(R, R)-\mathrm{Ac}_{6} \mathrm{c}^{35 \mathrm{dBu}}$ homopeptides.

\subsection{Conformational analysis in solution.}

In the FT-IR absorption spectra of homopeptides $\mathrm{Cbz}-\{(R, R)$ $\left.\mathrm{Ac}_{6} \mathrm{c}^{35 \mathrm{dBu}}\right\}_{\mathrm{n}}-\mathrm{OMe}(\mathrm{n}=1,2,3$ and 4) (Figure 2), no band was observed at approximately $3420-3440 \mathrm{~cm}^{-1}$ (free solvated N-H), whereas strong bands were noted at $3390-3370 \mathrm{~cm}^{-1}$, and this was attributed to the peptide $\mathrm{NH}$ group with intramolecular hydrogen bonds between peptide $\mathrm{N}-\mathrm{H}$ and acetal $-\mathrm{O}-$ (ether). In the tetrapeptide 9, a weak band was observed at $3330 \mathrm{~cm}^{-1}$, and may have been derived from the peptide $\mathrm{NH}$ groups with $\mathrm{N}-$ $\mathrm{H} \cdots \mathrm{O}=\mathrm{C}$ intramolecular hydrogen bonds.

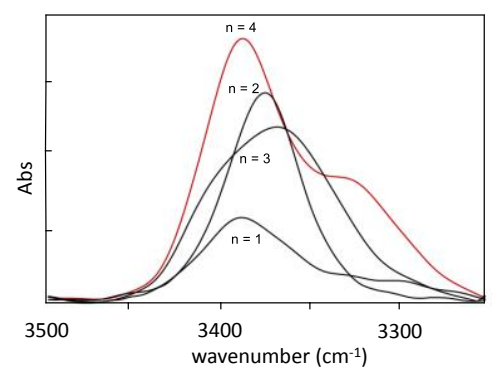

Fig. 2. FT-IR absorption spectra in the $\mathrm{N}-\mathrm{H}$ stretching region of homopeptides $\mathrm{Cbz}-\left\{(R, R)-\mathrm{Ac}_{6} \mathrm{c}^{35 \mathrm{dBu}}\right\}_{\mathrm{n}}-\mathrm{OMe}(\mathrm{n}=1,2,3$ and 4$)$ in $\mathrm{CDCl}_{3}$ solution. Peptide concentration: $5.0 \mathrm{mM}$.

Solvent perturbation experiments in the ${ }^{1} \mathrm{H}$ NMR spectrum of tetrapeptide 9 in $\mathrm{CDCl}_{3}$ solution $(1.0 \mathrm{mM})$ were performed by adding the strong hydrogen-bond acceptor solvent DMSO- $d_{6}(0-$ $10 \% \mathrm{v} / \mathrm{v})$ or paramagnetic free radical 2,2,6,6tetramethylpiperidin-1-yloxyl (TEMPO; $0-5 \times 10^{-2} \% \mathrm{w} / \mathrm{v}$ ). All $\mathrm{NH}$ chemical shifts were insensitive to the addition of DMSO- $d_{6}$. The bandwidth of $\mathrm{NH}$ signals was also not affected by the addition of the TEMPO radical (Fig. S1). ${ }^{6}$ These results demonstrated that all $\mathrm{NH}$ protons were solvent-shielded, suggesting that all $\mathrm{NH}$ protons were intramolecularly hydrogen bonded.

The CD spectrum of tetrapeptide 9 was measured in 2,2,2trifluoroethanol (TFE) solution. However, the characteristic maxima of a one-handed helical structure were not observed due to an insufficient peptide length (Fig. S2). ${ }^{6}$

\subsection{Structures of $(R, R)-\mathrm{Ac}_{6} \mathrm{c}^{35 \mathrm{dBu}}$ homochiral peptides in the crystal state.}

The $(R, R)-\mathrm{Ac}_{6} \mathrm{c}^{35 \mathrm{dBu}}$ homo-chiral dipeptide $\mathrm{Cbz}-\{(R, R)-$ $\left.\mathrm{Ac}_{6} \mathrm{c}^{35 \mathrm{dBu}}\right\}_{2}-\mathrm{OMe}(7)$ and tripeptide acid Cbz- $\left\{(R, R)-\mathrm{Ac}_{6} \mathrm{c}^{35 \mathrm{dBu}}\right\}_{3^{-}}$ $\mathrm{OH} 8$ ' provided crystals suitable for an X-ray crystallographic analysis following slow evaporation of the solvent at room temperature ( 7 from EtOH and $\mathbf{8}$ ' from petroleum ether/ $\mathrm{CHCl}_{3}$ ). The crystal and diffraction parameters of $\mathbf{7}$ and $\mathbf{8}$, are summarized in Table S1. ${ }^{6,7}$ Their molecular structures are given in Figures 3, 4, and Figure S3. ${ }^{6,8}$ Relevant backbone and sidechain torsion angles as well as the intra- and intermolecular hydrogen-bond parameters are listed in Tables 1 and 2.

Table 1. Selected torsion angles $\omega, \phi, \psi$, and $\chi\left[^{\circ}\right]$ for $\mathbf{7}$ and $\mathbf{8}^{\prime}$, as determined by an X-ray crystallographic analysis.

\begin{tabular}{|c|c|c|c|c|}
\hline \multirow{2}{*}{$\begin{array}{l}\text { TORSION } \\
\text { ANGLE }\end{array}$} & \multicolumn{2}{|c|}{ DIPEPTIDE (7) } & \multicolumn{2}{|c|}{ TRIPEPTIDE $\left(\boldsymbol{8}^{\prime}\right)$} \\
\hline & $A$ & $B$ & $C$ & $D$ \\
\hline$\omega 0$ & -174.4 & 172.3 & 170.5 & -171.7 \\
\hline$\phi 1$ & -66.5 & 68.4 & 62.6 & -59.6 \\
\hline$\psi 1$ & -26.4 & 27.8 & -145.8 & 142.0 \\
\hline$\omega 1$ & -174.9 & 176.8 & -167.8 & 166.1 \\
\hline$\phi 2$ & -52.5 & 51.1 & -52.5 & 55.6 \\
\hline$\psi 2$ & -34.3 & 35.6 & -40.4 & 38.7 \\
\hline$\omega 2$ & 175.2 & -173.0 & -173.8 & 173.8 \\
\hline$\phi 3$ & --- & --- & -61.1 & 63.8 \\
\hline$\psi 3$ & --- & --- & -24.8 & 23.4 \\
\hline$\chi 1$ & 63.8 & 68.2 & 65.9 & 62.1 \\
\hline
\end{tabular}




\begin{tabular}{rrrrr} 
& & & & Tetra \\
$1^{\prime}$ & -68.2 & -62.8 & -61.6 & -67.0 \\
$\chi 2$ & 65.9 & 68.9 & 67.0 & 67.3 \\
$\chi 2^{\prime}$ & -67.2 & -68.1 & -66.5 & -66.8 \\
$\chi 3$ & --- & --- & 66.5 & 71.4 \\
$\chi^{3}$ & --- & --- & -68.0 & -71.1 \\
\hline
\end{tabular}

Table 2. Intra- and intermolecular H-bond parameters for $\mathbf{7}$ and $\mathbf{8}$ '.

\begin{tabular}{|c|c|c|c|c|c|}
\hline \multirow[t]{2}{*}{$\begin{array}{c}\text { PEPTI } \\
\text { DE }\end{array}$} & \multirow[t]{2}{*}{$\begin{array}{c}\text { DONOR } \\
\text { D-H }\end{array}$} & $\begin{array}{c}\text { ACCEPT } \\
\text { OR }\end{array}$ & \multirow{2}{*}{ 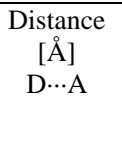 } & \multirow{2}{*}{$\begin{array}{c}\text { ANGLE } \\
{\left[{ }^{\circ}\right]} \\
\text { D-H. } \cdots A\end{array}$} & \multirow[t]{2}{*}{$\begin{array}{c}\text { SYMMETR } \\
\text { Y } \\
\text { Operations }\end{array}$} \\
\hline & & A & & & \\
\hline \multicolumn{6}{|c|}{$\mathrm{Cbz}-\left\{(R, R)-\mathrm{Ac}_{6} \mathrm{c}^{35 \mathrm{dBu}}\right\}_{2}-\mathrm{OMe}(\mathbf{7})$} \\
\hline \multirow[t]{2}{*}{$A(P)$} & $\mathrm{N}_{1 \mathrm{a}}-\mathrm{H}$ & $\mathrm{O}_{\text {la(acetal) }}$ & 2.85 & 117 & $\mathrm{x}, \mathrm{y}, \mathrm{z}$ \\
\hline & $\mathrm{N}_{2 \mathrm{a}}-\mathrm{H}$ & $\mathrm{O}_{2 \mathrm{a}(\text { acetal) }}$ & 2.83 & 128 & $\mathrm{x}, \mathrm{y}, \mathrm{z}$ \\
\hline \multirow[t]{4}{*}{$B(M)$} & $\mathrm{N}_{1 b}-\mathrm{H}$ & $\mathrm{O}_{\mathrm{lb}(\text { acetal) }}$ & 2.84 & 118 & $\mathrm{x}, \mathrm{y}, \mathrm{z}$ \\
\hline & $\mathrm{N}_{2 b}-\mathrm{H}$ & $\mathrm{O}_{2 \mathrm{~b} \text { (acetal) }}$ & 2.85 & 127 & $\mathrm{x}, \mathrm{y}, \mathrm{z}$ \\
\hline & $\mathrm{O}_{\mathrm{E}(\mathrm{a})}-\mathrm{H}$ & $\mathrm{O}_{2 \mathrm{a}}$ & 2.92 & 155 & $\mathrm{x}, \mathrm{y}, \mathrm{z}$ \\
\hline & $\mathrm{O}_{\mathrm{E}(\mathrm{b})}-\mathrm{H}$ & $\mathrm{O}_{2 \mathrm{~b}}$ & 2.96 & 162 & $\mathrm{x}, \mathrm{y}, \mathrm{z}$ \\
\hline \multicolumn{6}{|c|}{$\mathrm{Cbz}-\left\{(R, R)-\mathrm{Ac}_{6} \mathrm{c}^{35 \mathrm{dBu}}\right\}_{3}-\mathrm{OH}\left(\mathbf{8}^{\prime}\right)$} \\
\hline \multirow[t]{4}{*}{$C(P)$} & $\mathrm{N}_{1 \mathrm{a}}-\mathrm{H}$ & $\mathrm{O}_{\mathrm{la}(\text { acctal) }}$ & 2.83 & 126 & $\mathrm{x}, \mathrm{y}, \mathrm{z}$ \\
\hline & $\mathrm{N}_{2 \mathrm{a}}-\mathrm{H}$ & $\mathrm{O}_{2 \mathrm{a}(\text { acctal) }}$ & 2.81 & 130 & $\mathrm{x}, \mathrm{y}, \mathrm{z}$ \\
\hline & $\mathrm{N}_{3 \mathrm{a}}-\mathrm{H}$ & $\mathrm{O}_{3 a(\text { acctal })}$ & 2.83 & 122 & $\mathrm{x}, \mathrm{y}, \mathrm{z}$ \\
\hline & $\mathrm{O}_{3 \mathrm{a}}-\mathrm{H}$ & $\mathrm{O}_{1 \mathrm{a}}$ & 2.85 & 144 & $\mathrm{x}, \mathrm{y}, \mathrm{z}$ \\
\hline \multirow[t]{4}{*}{$D(M)$} & $\mathrm{N}_{1 b}-\mathrm{H}$ & $\mathrm{O}_{1 \mathrm{~b} \text { (acetal) }}$ & 2.85 & 126 & $\mathrm{x}, \mathrm{y}, \mathrm{z}$ \\
\hline & $\mathrm{N}_{2 \mathrm{~b}}-\mathrm{H}$ & $\mathrm{O}_{2 \mathrm{~b} \text { (acetal) }}$ & 2.79 & 128 & $\mathrm{x}, \mathrm{y}, \mathrm{z}$ \\
\hline & $\mathrm{N}_{3 b}-\mathrm{H}$ & $\mathrm{O}_{3 \mathrm{~b}(\text { acetal })}$ & 2.80 & 118 & $\mathrm{x}, \mathrm{y}, \mathrm{z}$ \\
\hline & $\mathrm{O}_{3 \mathrm{~b}}-\mathrm{H}$ & $\mathrm{O}_{1 \mathrm{~b}}$ & 2.89 & 146 & $\mathrm{x}, \mathrm{y}, \mathrm{z}$ \\
\hline
\end{tabular}

In the asymmetric unit of dipeptide 7, two crystallographically independent conformers $A$ and $B$ occurred along with two EtOH molecules. ${ }^{6}$ Based on the $\phi, \psi$ torsion angles, the conformer $A$ was a right-handed $(P)$ incipient helix while the conformer $B$ was a left-handed $(M)$ one. ${ }^{9}$ Torsion angles $\chi(\mathrm{N}-\mathrm{C} \alpha-\mathrm{C} \beta-\mathrm{C} \gamma)$ and $\chi$ ' $\left(\mathrm{N}-\mathrm{C} \alpha-\mathrm{C} \beta\right.$ ' $\left.-\mathrm{C} \gamma^{\prime}\right)$, relating the cyclohexyl ring to the peptide chain, namely $\mathrm{N}-\mathrm{C}^{1}-\mathrm{C}^{2}-\mathrm{C}^{3}$ (numbering of cyclohexane) and $\mathrm{N}-$ $C^{1}-C^{6}-C^{5}$, showed nearly $+60^{\circ}$ and $-60^{\circ}$, which indicated that the $-\mathrm{NH}-$ groups occupied the axial positions of chair form cyclohexane. $^{10}$

Neither an intra- nor an intermolecular hydrogen bond of the $\mathrm{N}-\mathrm{H} \cdots \mathrm{O}=\mathrm{C}$ type was observed, whereas the intramolecular hydrogen bonds of $\mathrm{N}-\mathrm{H} \cdots-\mathrm{O}-$ (acetal) type were detected. Therefore, hydrogen bonds were formed between peptide $\mathrm{N}(1 \mathrm{ab})-\mathrm{H}$ and the acetal $-\mathrm{O}-$ of the $\mathrm{N}$-terminal amino acid residue ( $1 \mathrm{ab})$ as well as between $\mathrm{N}(2 \mathrm{ab})-\mathrm{H}$ and the acetal $-\mathrm{O}-$ of the same amino acid residue (2ab) (Figure 3). Some distances between $\mathrm{N}(i$; donor) and the other acetal $-\mathrm{O}-$ (acceptor) of the same amino acid residue (i) were shorter than $3.0 \AA$; however their angles of $\mathrm{N}-\mathrm{H} \cdots \mathrm{O}$ were smaller than $90^{\circ}$, suggesting the absence of hydrogen bond formation between them. Toniolo and co-authors previously reported that similar intramolecular hydrogen bonds between peptide $\mathrm{N}-\mathrm{H}$ and side-chain acetal $-\mathrm{O}-$ were formed in $\mathrm{Hms}(\mathrm{Ipr})$ peptides. However, their hydrogen bonds were between peptide $\mathrm{N}(i)-\mathrm{H}$ and acetonide $-\mathrm{O}-$ of the amino acid residue $(i-l){ }^{4} \quad$ Therefore, the hydrogen bonding patterns of $\mathrm{Hms}(\mathrm{Ipr})$ peptides differed slightly from those of $(R, R)-\mathrm{Ac}_{6} \mathrm{c}^{35 \mathrm{dBu}}$ peptides. Furthermore, peptide backbone $\mathrm{N}(i)-\mathrm{H}$

\section{aron}

are known to be intramolecularly hydrogen-bonded with the same amino acid residue carbonyl group $\mathrm{O}(i)=\mathrm{C}(i)$ in the $\mathrm{C}_{5^{-}}$ conformation, but not with acetal $-\mathrm{O}-$.

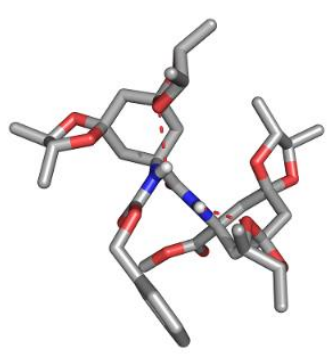

Fig. 3. Structure of Cbz- $\left\{(R, R)-\mathrm{Ac}_{6} \mathrm{c}^{35 \mathrm{dBu}}\right\}_{2}-\mathrm{OMe}(7$; conformer $A)$ as determined by an X-ray crystallographic analysis. Conformer $B$ and EtOH molecules were omitted for clarification. The hydrogen bonds are indicated as dashed lines.

The crystal structure of tripeptide acid $\mathbf{8}$ ' was solved in space group $P 2_{I}$ (Figure 4). Two crystallographically independent conformers $C$ and $D$ occurred in the asymmetric unit. ${ }^{6}$ The signs of peptide backbone torsion angles $\phi$ and $\psi$ were opposite between conformers $C$ and $D$. Therefore, although two peptide backbone structures in conformers $C$ and $D$ were almost mirror images, small conformational differences existed. According to the $\phi, \psi$ torsion angles of the residues ( 2 and 3 ), conformer $\mathrm{C}$ was a right-handed $(P)$ incipient helix while conformer $D$ was a lefthanded $(M)$ one. The torsion angles at the $\mathrm{N}$-terminal residue (1) in both conformers were the onset of the semi-extended conformation. ${ }^{9}$ Torsion angles $\chi$ and $\chi$ ' showed nearly $+60^{\circ}$ and $-60^{\circ}$, indicating that the $-\mathrm{NH}-$ groups occupied the axial positions of chair form cyclohexane.

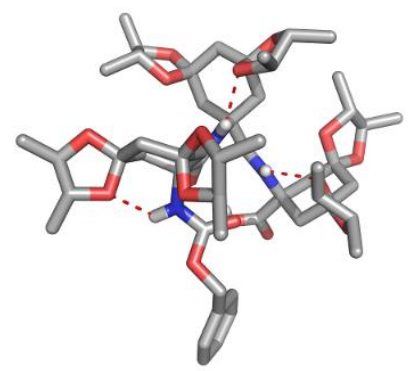

Fig. 4. Structure of Cbz- $\left\{(R, R)-\mathrm{Ac}_{6} \mathrm{c}^{35 \mathrm{dBu}}\right\}_{3}-\mathrm{OH}$ (8'; conformer $\left.C\right)$ as determined by an X-ray crystallographic analysis. Conformer $D$ was omitted for clarification. The hydrogen bonds are indicated as dashed lines.

In a similar manner to the dipeptide 7, the intramolecular hydrogen bonds of the $\mathrm{N}-\mathrm{H}$-..-O- (acetal) type were observed between peptide $\mathrm{N}(1 \mathrm{~cd})-\mathrm{H}$ and the acetal $-\mathrm{O}-(1 \mathrm{~cd})$ of the same amino acid residue, between $\mathrm{N}(2 \mathrm{~cd})-\mathrm{H}$ and the acetal $-\mathrm{O}-(2 \mathrm{~cd})$, and between $\mathrm{N}(3 \mathrm{~cd})-\mathrm{H}$ and the acetal $-\mathrm{O}-(3 \mathrm{~cd})$ in tripeptide $\mathbf{8}^{\prime}$. Thus, no intramolecular hydrogen bond of $\mathrm{N}-\mathrm{H} \cdots \mathrm{O}=\mathrm{C}$ type was observed. In addition, an intramolecular hydrogen bond was detected between the $\mathrm{C}$-terminal $\mathrm{O}(3 \mathrm{~cd})-\mathrm{H}$ and $\mathrm{O}(1 \mathrm{~cd})=\mathrm{C}(1 \mathrm{~cd})$ of the N-terminal residue (Fig. 5). This type of oxy-analog of a $\beta$-turn has already been observed in the crystal structure of $\mathrm{Cbz}-$ (Aib) ${ }_{3}-\mathrm{OH} .^{11}$

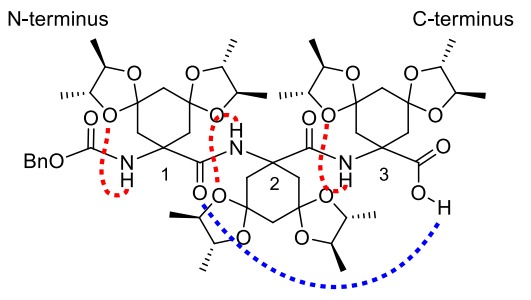


Fig. 5. Hydrogen bonding patterns of Cbz- $\left\{(R, R)-\mathrm{Ac}_{6} \mathrm{c}^{35 \mathrm{dBu}}\right\}_{3}-\mathrm{OH}(\mathbf{8})$.

The dipeptide $\mathbf{7}$ and tripeptide $\mathbf{8}$ ' formed two conformers showing both plus and minus signs of the $\phi, \psi$ torsion angles, which corresponded to right-handedness $(P)$ and left-handedness $(M)$, respectively; however, four chiral centers existed in one $(R, R)-\mathrm{Ac}_{6} \mathrm{c}^{35 \mathrm{dBu}}$ residue. Thus, the effect of four chiral centers in $(R, R)-\mathrm{Ac}_{6} \mathrm{c}^{35 \mathrm{dBu}}$ on the peptide backbone was very weak, as bicyclic amino acid side-chain chiral centers and six-membered ring amino acids with acetal chiral centers have weak bias to their peptide helical-screw handedness. ${ }^{5,12}$ All peptide $\mathrm{N}-\mathrm{H}$ were intramolecularly hydrogen-bonded with the acetal $-\mathrm{O}-$ of the same amino acid residues. These results were consistent with the absence of free NH groups in the FT-IR absorption spectra and ${ }^{1} \mathrm{H}$ NMR experiments.

\section{Conclusion}

We synthesized cyclic $\alpha, \alpha$-disubstituted amino acids with two chiral acetal moieties, and demonstrated that the acetal moiety was changeable. X-ray crystallographic analyses revealed that the effect of four chiral centers in one amino acid residue on their peptide helical-screw control was very weak. Peptide backbone $\mathrm{N}(i)-\mathrm{H}$ were also intramolecularly hydrogen-bonded with the acetal $-\mathrm{O}-$ of the same amino acid residues $(i)$. The property of $(R, R)-\mathrm{Ac}_{6} \mathrm{c}^{35 \mathrm{dBu}}$ was to form helical structures in its homopeptides, and the $\mathrm{N}-\mathrm{H} \cdot \cdots-\mathrm{O}-$ (acetal) type hydrogen bonds stabilized the helix, rather than destroying it and favoring other conformations. No such helical foldamers with these hydrogen bonding patterns have been reported to date. The changeable chiral acetal moiety may be introduced into other foldamers, such as $\beta$-, $\gamma$-peptides, and urea-peptides. Further studies on chiral organocatalysts using these chiral cyclic amino acid foldamers are currently ongoing. ${ }^{13}$

\section{Experimental Section}

\subsection{General}

Optical rotations $[\alpha]_{\mathrm{D}}$ were measured using a $1.0 \mathrm{dm}$ cell. Circular dichroism spectra (CD) were measured using a $1.0-\mathrm{mm}$ path length cell. Infrared spectra (IR) were recorded for conventional measurements (neat, or $\mathrm{KBr}$ ), and the solution $\left(\mathrm{CDCl}_{3}\right)$ method was performed using a $0.1-\mathrm{mm}$ path length of an $\mathrm{NaCl}$ cell. ${ }^{1} \mathrm{H}$ NMR spectra were determined at 400 or $500 \mathrm{MHz}$ at room temperature. $\mathrm{HRMS}(\mathrm{FAB})$ spectra were taken in the dual-focusing sector field mode, while HRMS(ESI) and HRMS(DART) spectra were measured in the TOF mode.

\subsection{Synthesis of amino acids}

4.2.1. Trimethyl 4-Oxopentane-1,2,2-tricarboxylate (1). A mixture of dimethyl malonate $(20.0 \mathrm{~g}, 152 \mathrm{mmol}), \mathrm{KOBu}^{t}(18.5$ $\mathrm{g}, 165 \mathrm{mmol})$, and bromoacetone $(4.0 \mathrm{~mL}, 165 \mathrm{mmol})$ in DMSO $(300 \mathrm{~mL})$ was stirred at room temperature under an $\mathrm{Ar}$ atmosphere for $4 \mathrm{~h}$. Then, $\mathrm{KOBu}^{t}(18.5 \mathrm{~g}, 165 \mathrm{mmol})$, and subsequently methyl bromoacetate $(15.6 \mathrm{~mL}, 165 \mathrm{mmol})$ were added to the stirred mixture. After being stirred at room temperature for $20 \mathrm{~h}$, the solution was diluted with $3 \%$ aqueous $\mathrm{HCl}$, extracted with EtOAc, and dried over $\mathrm{MgSO}_{4}$. After removal of the solvent, the residue was purified by column chromatography on silica gel (33\% EtOAc in $n$-hexane) to give $\mathbf{1}$ $(26.6 \mathrm{~g}, 67 \%)$ as a colorless oil: IR (neat) $\vee 2957,1730,1717$ $\mathrm{cm}^{-1} ;{ }^{1} \mathrm{H}$ NMR $\left(400 \mathrm{MHz}, \mathrm{CDCl}_{3}\right) \delta 3.74(\mathrm{~s}, 6 \mathrm{H}), 3.67(\mathrm{~s}, 3 \mathrm{H})$, $3.36(\mathrm{~s}, 2 \mathrm{H}), 3.17(\mathrm{~s}, 2 \mathrm{H}), 2.17(\mathrm{~s}, 3 \mathrm{H}) ;{ }^{13} \mathrm{C}$ NMR $(100 \mathrm{MHz}$, $\left.\mathrm{CDCl}_{3}\right) \delta$ 205.2, 171.2, 169.7, 53.0, 52.9, 51.8, 46.0, 37.1, 30.0; HRMS(DART): $[\mathrm{M}+\mathrm{H}]^{+}$, found 261.0969. $\mathrm{C}_{11} \mathrm{H}_{17} \mathrm{O}_{7}$ requires 261.0974 .

4.2.2. Dimethyl 3,5-Dioxocyclohexane-1,1-dicarboxylate (2). A solution of $1(5.00 \mathrm{~g}, 19.2 \mathrm{mmol})$ in DMF $(10 \mathrm{~mL})$ was added to the stirred mixture of $\mathrm{NaH}(1.15 \mathrm{~g}, 28.8 \mathrm{mmol})$ in DMF $(70 \mathrm{~mL})$ at $0{ }^{\circ} \mathrm{C}$. After being stirred at room temperature for $3 \mathrm{~h}$, the solution was neutralized with $2 \%$ aqueous $\mathrm{HCl}$, extracted with EtOAc, and dried over $\mathrm{MgSO}_{4}$. Removal of the solvent gave a white solid, which was purified by column chromatography on silica gel. The fraction eluted with $10 \% \mathrm{MeOH}$ in $\mathrm{CHCl}_{3}$ afforded diketone 2 (3.91 g, 89\%) as colorless crystals: $\mathrm{mp} \mathrm{133-}$ $134{ }^{\circ} \mathrm{C}$; IR $\vee(\mathrm{KBr}) 3700-2250$ (br), 1748, 1732, $1628 \mathrm{~cm}^{-1} ;{ }^{1} \mathrm{H}$ NMR (400 MHz, $\left.\mathrm{CDCl}_{3}\right) \delta 5.50$ (br s, 0.6H), 5.44 (s, 0.6H), 3.79, $3.76(\mathrm{~s}$, total $6 \mathrm{H}), 3.37(\mathrm{~s}, 0.8 \mathrm{H}), 3.05,2.96(\mathrm{~s}$, total $4 \mathrm{H}) ;{ }^{13} \mathrm{C}$ NMR $\left(100 \mathrm{MHz}, \mathrm{CDCl}_{3}\right) \delta 200.2,187.7,169.7,103.8,54.3$, 53.4, 45.0, 37.5; HRMS(DART): $[\mathrm{M}+\mathrm{H}]^{+}$, found 229.0696. $\mathrm{C}_{10} \mathrm{H}_{13} \mathrm{O}_{6}$ requires 229.0712 .

4.2.3. Dimethyl 3,3,5,5-Bis\{(2R,3R)-butane-2,3dioxy\}cyclohexane-1,1-dicarboxylate (3a). A solution of diketone 2 (5.00 g, $21.9 \mathrm{mmol}),(2 R, 3 R)$-butane-2,3-diol $(4.14 \mathrm{~g}$, $46.0 \mathrm{mmol})$ and $p$ - $\mathrm{TsOH} \cdot \mathrm{H}_{2} \mathrm{O}(220 \mathrm{mg})$ in benzene $(100 \mathrm{~mL})$ was refluxed for $20 \mathrm{~h}$, fixed with a Dean-stark apparatus. After being cooled to room temperature, the solution was washed with $5 \%$ aqueous $\mathrm{NaHCO}_{3}$, brine, and dried over $\mathrm{MgSO}_{4}$. Removal of the solvent gave a white solid, which was purified by column chromatography on silica gel (50\% ether in $n$-hexane) to produce diacetal 3a $(7.95 \mathrm{~g}, 98 \%)$ as colorless crystals: $\mathrm{mp} 113-115^{\circ} \mathrm{C}$ (recryst. from $n$-hexane); $[\alpha]^{23}{ }_{\mathrm{D}}-13.4$ (c 1.04, $\left.\mathrm{CHCl}_{3}\right)$; IR $\left(\mathrm{CDCl}_{3}\right) \vee 2978,2884,1737 \mathrm{~cm}^{-1} ;{ }^{1} \mathrm{H}$ NMR $\left(400 \mathrm{MHz}, \mathrm{CDCl}_{3}\right) \delta$ $3.71-3.65(\mathrm{~m}, 2 \mathrm{H}), 3.71(\mathrm{~s}, 6 \mathrm{H}), 3.59-3.52(\mathrm{~m}, 2 \mathrm{H}), 2.45(\mathrm{~d}, J=$ $14.0 \mathrm{~Hz}, 2 \mathrm{H}), 2.32(\mathrm{~d}, J=14.0 \mathrm{~Hz}, 2 \mathrm{H}), 2.00(\mathrm{~s}, 2 \mathrm{H}), 1.22-1.20$ $(\mathrm{m}, 12 \mathrm{H}) ;{ }^{13} \mathrm{C}$ NMR $\left(100 \mathrm{MHz}, \mathrm{CDCl}_{3}\right) \delta 171.1,106.9,78.5$, 77.9, 53.1, 52.6, 46.9, 38.2, 17.2, 16.7; HRMS(DART): [M+H] ${ }^{+}$, found 373.1848. $\mathrm{C}_{18} \mathrm{H}_{29} \mathrm{O}_{8}$ requires 373.1862.

4.2.4. Methyl 1-(Benzyloxycarbonyl)amino-3,3,5,5-bis\{(2R,3R)butane-2,3-dioxy\}cyclohexane-1-carboxylate [Cbz-\{(R,R)$\left.A c_{6} c^{35 d B u}\right\}$-OMe; 4a $]$. A solution of diester 3a (7.95 g, 21.4 $\mathrm{mmol})$ in $\mathrm{MeOH}(70 \mathrm{~mL})$ and aqueous $\mathrm{NaOH}$ of $0.1 \mathrm{M}(200 \mathrm{~mL})$ was stirred overnight at room temperature. Then, the solution was neutralized with citric acid and $\mathrm{MeOH}$ was evaporated. The aqueous solution was extracted with $\mathrm{CHCl}_{3}$ and dried over $\mathrm{MgSO}_{4}$. Removal of the solvent afforded a crude carboxylic acid $(7.4 \mathrm{~g})$, which was used in the next reaction without purification. A mixture of the crude carboxylic acid $(7.4 \mathrm{~g}), \mathrm{Et}_{3} \mathrm{~N}(3.2 \mathrm{~mL})$ and diphenylphosphoryl azide (DPPA, $4.80 \mathrm{~mL}, 22.3 \mathrm{mmol}$ ) in toluene $(150 \mathrm{~mL})$ was refluxed for $2 \mathrm{~h}$. Then, benzyl alcohol $(\mathrm{BnOH} ; 3.15 \mathrm{~mL}, 30.5 \mathrm{mmol})$ was added to the solution, and the solution was refluxed for $20 \mathrm{~h}$. After evaporation, the residue was diluted with EtOAc, washed with $5 \%$ aqueous $\mathrm{NaHCO}_{3}$, brine and dried over $\mathrm{MgSO}_{4}$. Removal of the solvent afforded a residue, which was purified by column chromatography on silica gel. The fraction eluted with $50 \%$ ether in $n$-hexane gave cyclic amino acid $4 a(6.76 \mathrm{~g}, 68 \%)$ as a yellowish oil: $[\alpha]^{22}-4.89(c$ $\left.1.03, \mathrm{CHCl}_{3}\right) ; \mathrm{IR}\left(\mathrm{CDCl}_{3}\right) \vee 3398,3019,1742,1714,1275 \mathrm{~cm}^{-1}$; ${ }^{1} \mathrm{H}$ NMR $\left(400 \mathrm{MHz}, \mathrm{CDCl}_{3}\right) \delta 7.38-7.26(\mathrm{~m}, 5 \mathrm{H}), 6.62(\mathrm{br} \mathrm{s}$, $1 \mathrm{H}), 5.13(\mathrm{~d}, J=12.2 \mathrm{~Hz}, 1 \mathrm{H}), 5.02$ (d, $J=12.2 \mathrm{~Hz}, 1 \mathrm{H}), 3.75$ (s, 
$3 \mathrm{H}), 3.68-3.48(\mathrm{~m}, 4 \mathrm{H}), 2.34(\mathrm{~d}, J=14.2 \mathrm{~Hz}, 2 \mathrm{H}), 2.04-1.90$ $(\mathrm{m}, 4 \mathrm{H}), 1.25-1.15(\mathrm{~m}, 12 \mathrm{H}) ;{ }^{13} \mathrm{C}$ NMR $\left(100 \mathrm{MHz}, \mathrm{CDCl}_{3}\right)$ $\delta 173.0,155.6,136.7,128.3,128.1,127.9,107.2,79.2,79.0$, $77.5,77.4,66.3,58.9,52.7,46.0,40.6,39.0,17.0,16.9,16.8$, 16.5; HRMS(DART): $[\mathrm{M}+\mathrm{H}]^{+}$, found 464.2304. $\mathrm{C}_{24} \mathrm{H}_{34} \mathrm{NO}_{8}$ requires 464.2284 .

4.2.5. Dimethyl 3,3,5,5-Bis\{(2R,4R)-pentane-2,4dioxy ; cyclohexane-1,1-dicarboxylate $(\mathbf{3 b})$. Compound $\mathbf{3 b}$ was prepared from 2 and $(2 R, 4 R)$-pentane-2,4-diol in a manner similar to that described for the preparation of 3a. Colorless crystals. $62 \% ; \mathrm{mp} 114-116{ }^{\circ} \mathrm{C}$ (recryst. from $n$-hexane/ $\mathrm{Et}_{2} \mathrm{O}$ ); $[\alpha]^{24}-35.4\left(c 1.00, \mathrm{CHCl}_{3}\right)$; IR (neat) v 2970, 1740, $1443 \mathrm{~m}^{-1}$; ${ }^{1} \mathrm{H}$ NMR (400 MHz, $\mathrm{CDCl}_{3}$ ) $\delta 4.02(\mathrm{~m}, 2 \mathrm{H}), 3.89(\mathrm{~m}, 2 \mathrm{H}), 3.68$ (s, 6H), $2.52(\mathrm{~d}, J=14.0 \mathrm{~Hz}, 2 \mathrm{H}), 2.24(\mathrm{~d}, J=14.0 \mathrm{~Hz}, 2 \mathrm{H}), 2.03$ (s, 2H), 1.58-1.50 (m, 4H), 1.14-1.10 (m, 12H); ${ }^{13} \mathrm{C}$ NMR (100 $\left.\mathrm{MHz}, \mathrm{CDCl}_{3}\right) \delta 171.2,99.6,62.6,62.5,53.2,52.5,42.4,41.1$, $36.3,21.5,21.5$; HRMS(DART): $[\mathrm{M}+\mathrm{H}]^{+}$, found 401.2168 . $\mathrm{C}_{20} \mathrm{H}_{33} \mathrm{O}_{8}$ requires 401.2175 .

4.2.6. Methyl 1-(Benzyloxycarbonyl)amino-3,3,5,5-bis\{(2R,4R)pentane-2,4-dioxy\}cyclohexane-1-carboxylate [Cbz-\{(R,R)$\left.\left.A c_{6} c^{35 d P e n}\right\}-O M e ; 4 \boldsymbol{b}\right]$. Cyclic amino acid $\mathbf{4 b}$ was prepared from $\mathbf{3 b}$ in a manner similar to that described for the preparation of $\mathbf{4 a}$. A yellowish oil. $31 \%$; $[\alpha]_{D}^{25}-34.7\left(c 1.00, \mathrm{CHCl}_{3}\right)$; IR (neat) $v$ 3387 (br), 2974, 1748, 1720, $1505 \mathrm{~m}^{-1}$; ${ }^{1} \mathrm{H}$ NMR (400 MHz, $\left.\mathrm{CDCl}_{3}\right) \delta 7.38-7.27(\mathrm{~m}, 5 \mathrm{H}), 6.81(\mathrm{br} \mathrm{s}, 1 \mathrm{H}), 5.12(\mathrm{~d}, J=12.5$ $\mathrm{Hz}, 1 \mathrm{H}), 5.02(\mathrm{~d}, J=12.5 \mathrm{~Hz}, 1 \mathrm{H}), 4.02-3.90(\mathrm{~m}, 3 \mathrm{H}), 3.79(\mathrm{~m}$, 1H), 3.74 (s, 3H), 2.69-2.62 (m, 2H), 2.47 (br d, $J=13.6 \mathrm{~Hz}$, $1 \mathrm{H}), 1.87(\mathrm{~d}, J=14.2 \mathrm{~Hz}, 1 \mathrm{H}), 1.74(\mathrm{~d}, J=14.2 \mathrm{~Hz}, 1 \mathrm{H}), 1.62-$ $1.42(\mathrm{~m}, 5 \mathrm{H}), 1.20-1.08(\mathrm{~m}, 9 \mathrm{H}), 1.00(\mathrm{~d}, J=6.1 \mathrm{~Hz}, 3 \mathrm{H}),{ }^{13} \mathrm{C}$ NMR $\left(100 \mathrm{MHz}, \mathrm{CDCl}_{3}\right) \delta 173.0,155.4,136.6,128.2,127.9$, $127.7,100.1,99.9,66.1,63.1,62.6,62.2,58.7,52.5,40.9,40.8$, 40.7, 35.5, 21.4, 21.3, 21.2; HRMS(DART): $[\mathrm{M}+\mathrm{H}]^{+}$, found 492.2570. $\mathrm{C}_{26} \mathrm{H}_{38} \mathrm{NO}_{8}$ requires 492.2597.

4.2.7. Dimethyl 3,3,5,5-Bis\{(R,R)-cyclohexane-1,2dioxy cyclohexane-1,1-dicarboxylate $(\mathbf{3 c})$. Compound $\mathbf{3 c}$ was prepared from 2 and $(R, R)$-cyclohexane-1,2-diol in a manner similar to that described for the preparation of 3a. Colorless crystals. $24 \%$; mp $103-105^{\circ} \mathrm{C}$; $[\alpha]^{23}{ }_{\mathrm{D}}-9.5$ (c 2.00, $\left.\mathrm{CHCl}_{3}\right)$; IR (neat) $v 3017,2943,2870,1744,1447,1350,1242 \mathrm{~m}^{-1}$; ${ }^{1} \mathrm{H} \mathrm{NMR}$ $\left(400 \mathrm{MHz}, \mathrm{CDCl}_{3}\right) \delta 3.70(\mathrm{~s}, 6 \mathrm{H}), 3.27(\mathrm{~m}, 2 \mathrm{H}), 3.17(\mathrm{~m}, 2 \mathrm{H})$, $2.46(\mathrm{~d}, J=14.1 \mathrm{~Hz}, 2 \mathrm{H}), 2.43(\mathrm{~d}, J=14.1 \mathrm{~Hz}, 2 \mathrm{H}), 2.12-2.05$ (m, 6H), 1.80-1.70 (br m, 4H), 1.45-1.20 (m, 8H); ${ }^{13} \mathrm{C}$ NMR $\left(100 \mathrm{MHz}, \mathrm{CDCl}_{3}\right) \delta 171.1,107.5,80.1,79.8,52.8,52.6,46.5$, 38.1, 28.9, 28.7, 23.6, 23.6; HRMS(DART): $[\mathrm{M}+\mathrm{H}]^{+}$, found 425.2189. $\mathrm{C}_{22} \mathrm{H}_{33} \mathrm{O}_{8}$ requires 425.2175 .

4.2.8. Methyl 1-(Benzyloxycarbonyl)amino-3,3,5,5-bis\{(R,R)cyclohexane-1,2-dioxy\}cyclohexane-1-carboxylate [Cbz-\{(R,R)$\left.\left.A c_{6} c^{35 d C y c}\right\}-O M e ; 4 c\right]$. Cyclic amino acid $4 c$ was prepared from $\mathbf{3 c}$ in a manner similar to that described for the preparation of $\mathbf{4 a}$. A yellowish oil. $49 \%$; $[\alpha]^{19}{ }_{\mathrm{D}}-9.4\left(c 1.00, \mathrm{CHCl}_{3}\right)$; IR (neat) $v$ 3395 (br), 2943, 2874, 1713 (br), $1505 \mathrm{~cm}^{-1}$; ${ }^{1} \mathrm{H}$ NMR (400 $\left.\mathrm{MHz} \mathrm{CDCl}_{3}\right) \delta 7.40-7.25(\mathrm{~m}, 5 \mathrm{H}), 6.65$ (br s, $\left.1 \mathrm{H}\right), 5.18-5.00$ $(\mathrm{m}, 2 \mathrm{H}), 3.75(\mathrm{~s}, 3 \mathrm{H}), 3.30-3.10(\mathrm{~m}, 4 \mathrm{H}), 2.32-2.48(\mathrm{~m}, 2 \mathrm{H})$, $2.13-1.90(\mathrm{~m}, 6 \mathrm{H}), 1.85-1.70(\mathrm{~m}, 4 \mathrm{H}), 1.50-1.15(\mathrm{~m}, 10 \mathrm{H}) ;{ }^{13} \mathrm{C}$ NMR $\left(100 \mathrm{MHz}, \mathrm{CDCl}_{3}\right) \delta 173.0,155.7,136.8,128.3,128.2$, 127.9, 108.0, 107.9, 81.0, 80.9, 79.4, 79.2, 66.4, 58.9, 52.7, 45.5, 40.6, 38.9, 28.9, 28.8, 28.7, 28.7, 23.7, 23.6; HRMS(DART): $[\mathrm{M}+\mathrm{H}]^{+}$, found 516.2623. $\mathrm{C}_{28} \mathrm{H}_{38} \mathrm{NO}_{8}$ requires 516.2597.

4.2.9. 1-(Benzyloxycarbonyl)amino-3,3,5,5-bis\{(2R,3R)-butane2,3-dioxy $\}$ cyclohexane-1-carboxylic acid [Cbz- $\left\{(\mathrm{R}, \mathrm{R})-A c_{6} c^{35 d B u}\right\}$ $\mathrm{OH} ; \mathbf{5}$ ]. A solution of $\mathbf{4 a}(2.00 \mathrm{~g}, 4.31 \mathrm{mmol})$ in $\mathrm{MeOH}(30 \mathrm{~mL})$ and aqueous $\mathrm{NaOH}$ of $1 \mathrm{M}(20 \mathrm{~mL})$ was stirred at room temperature for 4 days. After removal of $\mathrm{MeOH}$, the solution was neutralized with citric acid, extracted with $\mathrm{CHCl}_{3}$, and dried over $\mathrm{MgSO}_{4}$. Removal of the solvent afforded a crude carboxylic acid 5 (1.90 g, quantitative) as colorless crystals. mp 101-103 ${ }^{\circ} \mathrm{C} ;[\alpha]^{23}{ }_{\mathrm{D}}-12.3\left(c 1.00, \mathrm{CHCl}_{3}\right) ; \mathrm{IR}\left(\mathrm{CDCl}_{3}\right) \vee 3022,2971,2890$, 1748, 1717, $1524 \mathrm{~cm}^{-1} ;{ }^{1} \mathrm{H}$ NMR (400 MHz, $\left.\mathrm{CDCl}_{3}\right) \delta 7.40-7.30$ (m, 5H), 6.73 (br s, 1H), 5.17 (d, $J=12.3 \mathrm{~Hz}, 1 \mathrm{H}), 5.06(\mathrm{~d}, J=$ $12.3 \mathrm{~Hz}, 1 \mathrm{H}), 3.72-3.50(\mathrm{~m}, 4 \mathrm{H}), 2.39$ (br d, $J=14.3 \mathrm{~Hz}, 2 \mathrm{H})$, 2.05-1.92 (m, 4H), 1.25-1.15 (m, 12H); ${ }^{13} \mathrm{C}$ NMR (100 MHz, $\left.\mathrm{CDCl}_{3}\right) \delta 176.3,156.3,136.4,128.3,128.2,127.9,107.2,79.2$, 79.0, 77.5, 66.7, 59.0, 45.9, 40.3, 38.7, 17.0, 16.9, 16.7, 16.5; HRMS(DART): $[\mathrm{M}+\mathrm{H}]^{+}$, found 450.2153. $\mathrm{C}_{23} \mathrm{H}_{32} \mathrm{NO}_{8}$ requires 450.2128 .

4.2.10. Methyl 1-Amino-3,3,5,5-bis\{(2R,3R)-butane-2,3dioxy $\}$ cyclohexane-1-carboxylate $\left[H-\left\{(\mathrm{R}, \mathrm{R})-A c_{6} c^{35 d B u}\right\}-O M e ; 6\right]$. A mixture of $4 \mathrm{a}(3.30 \mathrm{~g}, 7.12 \mathrm{mmol})$ and $5 \% \mathrm{Pd}-\mathrm{C}(3 \mathrm{~g})$ in $\mathrm{MeOH}(50 \mathrm{~mL})$ was rigorously stirred at room temperature under $\mathrm{a} \mathrm{H}_{2}$ atmosphere for $14 \mathrm{~h}$. Then, the Pd-C was filtered off, and the filtrate was evaporated. The oily residue was purified by column chromatography on silica gel $\left(10 \% \mathrm{MeOH}\right.$ in $\left.\mathrm{CHCl}_{3}\right)$ to give amine $6(2.18 \mathrm{~g}, 93 \%)$ as a colorless oil. $[\alpha]^{19}{ }_{\mathrm{D}}-28.0(\mathrm{c}$ 1.00, $\mathrm{CHCl}_{3}$ ); IR (neat) v 3391 (br), 2974, 2931, 2878, 1740, $1443 \mathrm{~cm}^{-1}$; ${ }_{1}^{1} \mathrm{H}$ NMR $\left(400 \mathrm{MHz}, \mathrm{CDCl}_{3}\right) \delta 3.85-3.50(\mathrm{~m}, 4 \mathrm{H})$, 3.75 (s, 3H), 3.10 (br s, 2H), 2.20-1.85 (m, 6H), 1.32-1.20 (m, $12 \mathrm{H}) ;{ }^{13} \mathrm{C}$ NMR $\left(100 \mathrm{MHz}, \mathrm{CDCl}_{3}\right) \delta 171.7,106.8,106.6,79.5$, 78.8, 77.8, 77.7, 59.2, 52.9, 45.6, 42.0, 40.4, 17.0, 16.8, 16.5, 16.4; HRMS(DART): $[\mathrm{M}+\mathrm{H}]^{+}$, found 330.1905. $\mathrm{C}_{16} \mathrm{H}_{28} \mathrm{NO}_{6}$ requires 330.1917 .

\subsection{Preparation of peptides}

4.3.1. Dipeptide [Cbz-\{(R,R)-Ac $\left.\left.c_{6} c^{35 d B u}\right\}_{2}-\mathrm{OMe} ; 7\right]$. A solution of acid 5 (1.19 g, $2.65 \mathrm{mmol}), \operatorname{EtPr}_{2}^{i} \mathrm{~N}(0.92 \mathrm{~mL}, 5.30 \mathrm{mmol})$, and HBTU (1.50 g, $4.00 \mathrm{mmol}$ ) in $\mathrm{MeCN}(35 \mathrm{~mL})$ was stirred at room temperature for $7 \mathrm{~h}$. Then, amine $6(0.550 \mathrm{~g}, 1.67 \mathrm{mmol})$ in $\mathrm{MeCN}(5 \mathrm{~mL})$ was added to the stirred solution, and the solution was stirred at $60{ }^{\circ} \mathrm{C}$ for $12 \mathrm{~h}$. After removal of the solvent, the residue was diluted with EtOAc, washed with $5 \%$ aqueous $\mathrm{NaHCO}_{3}$, brine, and dried over $\mathrm{MgSO}_{4}$. Removal of the solvent afforded a white solid, which was purified by column chromatography on silica gel $(60 \%$ EtOAc in $n$-hexane) to produce dipeptide $7(0.840 \mathrm{~g}, 66 \%)$ as colorless crystals: $\mathrm{mp} 82-$ $84{ }^{\circ} \mathrm{C}$ (recryst. from EtOH); [Found: C, 61.41; H, 7.35; N, 3.71. $\mathrm{C}_{39} \mathrm{H}_{56} \mathrm{~N}_{2} \mathrm{O}_{13}$ : requires $\left.\mathrm{C}, 61.56 ; \mathrm{H}, 7.42 ; \mathrm{N}, 3.68 \%\right] ;[\alpha]^{23}{ }_{\mathrm{D}}-6.54$ (c 1.00, $\mathrm{CHCl}_{3}$ ); IR (neat) v 3379 (br), 2974, 1732, 1678, 1512 $\mathrm{cm}^{-1}$; ${ }^{1} \mathrm{H}$ NMR $\left(400 \mathrm{MHz}, \mathrm{CDCl}_{3}\right) \delta 8.17$ (br s, $\left.1 \mathrm{H}\right), 7.45-7.25$ (m, 5H), 6.55 (br s, 1H), 5.09 (m, 2H), 3.72 (br s, 3H), 3.72-3.45 (m, 8H), $2.52(\mathrm{~m}, 1 \mathrm{H}), 2.40-2.30(\mathrm{~m}, 2 \mathrm{H}), 2.16(\mathrm{~m}, 1 \mathrm{H}), 2.00-$ $1.85(\mathrm{~m}, 8 \mathrm{H}), 1.30-1.10(\mathrm{~m}, 24 \mathrm{H}) ;{ }^{13} \mathrm{C} \mathrm{NMR}\left(100 \mathrm{MHz}, \mathrm{CDCl}_{3}\right)$ $\delta 172.6,170.9,155.3,137.1,128.3,127.8,107.9,107.7,107.5$, 107.4, 79.0, 78.9, 78.6, 77.4, 65.9, 59.3, 57.8, 52.4, 46.1, 45.9, $41.5,40.9,38.1,36.8,17.0,16.9,16.8,16.5,16.5,16.3$.

4.3.2. Tripeptide $\left[\mathrm{Cbz}-\left\{(\mathrm{R}, \mathrm{R})-A c_{6} c^{35 d B u}\right\}_{3}-\mathrm{OMe} ; 8\right]$. A solution of $7(800 \mathrm{mg}, 1.05 \mathrm{mmol})$ in $\mathrm{MeOH}(22 \mathrm{~mL})$ and aqueous $\mathrm{NaOH}$ of $1 \mathrm{M}(10.5 \mathrm{~mL})$ was stirred at room temperature for 3 days. After removal of $\mathrm{MeOH}$, the solution was neutralized with citric acid, extracted with $\mathrm{CHCl}_{3}$, dried over $\mathrm{Na}_{2} \mathrm{SO}_{4}$. Removal of the solvent gave a crude dipeptide acid $(688 \mathrm{mg})$, which was used without further purification. A solution of dipeptide acid (688 $\mathrm{mg}), \operatorname{EtPr}_{2}^{i} \mathrm{~N}(0.92 \mathrm{~mL})$, HBTU (420 mg, $\left.1.10 \mathrm{mmol}\right)$, and $\mathrm{HOBt} \cdot \mathrm{H}_{2} \mathrm{O}(168 \mathrm{mg}, 1.10 \mathrm{mmol})$ in $\mathrm{MeCN}(20 \mathrm{~mL})$ was stirred at room temperature for $4 \mathrm{~h}$. Then, amine $\mathbf{4 a}(362 \mathrm{mg}, 1.10 \mathrm{mmol})$ in $\mathrm{MeCN}(5 \mathrm{~mL})$ was added, and the mixture was refluxed for 38 h. After removal of the solvent, the residue was diluted with EtOAc, washed with $5 \%$ aqueous $\mathrm{NaHCO}_{3}$, brine, and dried over $\mathrm{MgSO}_{4}$. Removal of the solvent gave a white solid, which was purified by column chromatography on silica gel. The fraction 
eluted with $60 \%$ EtOAc in $n$-hexane afforded tripeptide 8 (745 $\mathrm{mg}, 67 \%)$ as colorless crystals: $\mathrm{mp} 102-104{ }^{\circ} \mathrm{C} ;[\alpha]^{23}{ }_{\mathrm{D}}-23.2(\mathrm{c}$ 1.00, $\left.\mathrm{CHCl}_{3}\right)$; IR $\left(\mathrm{CDCl}_{3}\right) \vee 3369$ (br), 2975, 2934, 1722, 1682 $\mathrm{cm}^{-1} ;{ }^{1} \mathrm{H}$ NMR $\left(400 \mathrm{MHz}, \mathrm{CDCl}_{3}\right) \delta 7.91$ (br s, 1H), 7.69 (br s, $1 \mathrm{H}), 7.40-7.25(\mathrm{~m}, 5 \mathrm{H}), 6.61($ br s, $1 \mathrm{H}), 5.10(\mathrm{~d}, J=12.5 \mathrm{~Hz}$, $1 \mathrm{H}), 5.07(\mathrm{~d}, J=12.5 \mathrm{~Hz}, 1 \mathrm{H}), 3.75-3.45(\mathrm{~m}, 12 \mathrm{H}), 3.67(\mathrm{~s}, 3 \mathrm{H})$, 2.55-2.42 (m, 2H), 2.40-2.15 (m, 6H), 2.06-1.85 (m, 10H), $1.28-1.10(\mathrm{~m}, 36 \mathrm{H}) ;{ }^{13} \mathrm{C} \mathrm{NMR}\left(100 \mathrm{MHz}, \mathrm{CDCl}_{3}\right) \delta 173.4$, $170.9,170.5,155.7,137.0,128.4,128.1,127.9,108.2,108.0$, $107.9,107.7,107.5,107.4,79.0,78.9,78.7,78.5,78.2,77.9$, $77.4,66.1,59.7,58.7,58.0,52.2,46.2,46.1,46.1,41.7,40.9$, 40.7, 39.3, 37.7, 36.9, 17.1, 17.0, 16.9, 16.8, 16.7, 16.6, 16.5; HRMS(FAB): $[\mathrm{M}+\mathrm{H}]^{+}$, found $1058.5435 . \mathrm{C}_{54} \mathrm{H}_{80} \mathrm{~N}_{3} \mathrm{O}_{18}$ requires 1058.5437

4.3.3. Tripeptide acid [Cbz-\{(R,R)-Ac $\left.c_{6} \mathrm{C}^{35 d \mathrm{dBu}}\right\}_{3} \mathrm{OH} ; \quad \boldsymbol{8}$ ']. A solution of tripeptide $8(524 \mathrm{mg}, 0.500 \mathrm{mmol})$ in $\mathrm{MeOH}(8 \mathrm{~mL})$ and aqueous $\mathrm{NaOH}$ of $1 \mathrm{M}(5 \mathrm{~mL})$ was stirred at room temperature for 2 days. After removal of the $\mathrm{MeOH}$, the solution was acidified with citric acid, extracted with $\mathrm{CHCl}_{3}$, and dried over $\mathrm{Na}_{2} \mathrm{SO}_{4}$. Removal of the solvent gave a crude tripeptide acid 8' (431 $\mathrm{mg}, 83 \%$ ) as colorless crystals: $\mathrm{mp} 119-121{ }^{\circ} \mathrm{C}$; $[\alpha]_{D}^{23}-24.3$ (c 1.00, $\left.\mathrm{CHCl}_{3}\right)$; IR $\left(\mathrm{CDCl}_{3}\right) \vee 3850$ (br), 3383, 2976, 1749, 1708, 1687, $1660 \mathrm{~cm}^{-1}$; ${ }^{1} \mathrm{H}$ NMR (400 MHz, $\left.\mathrm{CDCl}_{3}\right)$ $\delta 10.19$ (br s, 1H), 8.26 (br s, 1H), 7.59 (br s, $1 \mathrm{H}), 7.35-7.20(\mathrm{~m}$, $5 \mathrm{H}), 6.69(\mathrm{br} \mathrm{s}, 1 \mathrm{H}), 5.03(\mathrm{~d}, J=12.5 \mathrm{~Hz}, 1 \mathrm{H}), 4.99(\mathrm{~d}, J=12.5$ $\mathrm{Hz}, 1 \mathrm{H}), 3.73-3.43(\mathrm{~m}, 12 \mathrm{H}), 2.78(\mathrm{~m}, 1 \mathrm{H}), 2.30-2.45(\mathrm{~m}, 2 \mathrm{H})$, $2.30-2.12(\mathrm{~m}, 5 \mathrm{H}), 2.08-1.82(\mathrm{~m}, 10 \mathrm{H}), 1.30-1.10(\mathrm{~m}, 36 \mathrm{H}) ;{ }^{13} \mathrm{C}$ NMR $\left(100 \mathrm{MHz}, \mathrm{CDCl}_{3}\right) \delta 173.7,172.9,170.1,155.6,136.8$, $128.4,127.8,127.0,108.1,107.9,107.8,107.6,107.4,107.3$, $79.2,79.0,78.6,78.5,77.8,77.5,77.3,66.1,60.0,59.3,59.1$, $46.4,46.0,45.9,41.8,40.8,39.7,39.2,37.4,36.9,17.1,17.0$, $17.0,16.9,16.8,16.8,16.7,16.5,16.5,16.4,16.2,15.8$; HRMS(ESI): $[\mathrm{M}+\mathrm{H}]^{+}$, found 1044.5306. $\mathrm{C}_{53} \mathrm{H}_{78} \mathrm{~N}_{3} \mathrm{O}_{18}$ requires 1044.5280 .

4.3.4. Tetrapeptide [Cbz-\{(R,R)-Ac $\left.c_{6} c^{35 d B u}\right\}_{4}$-OMe; 9]. Tetrapeptide $\mathbf{9}$ was prepared from tripeptide acid $\mathbf{8}$, and amine $\mathbf{6}$ using HATU and HOAt as coupling reagents in a manner similar to that described for the preparation of $\mathbf{8}$. Colorless crystals. 66\%; mp 125-127 ${ }^{\circ} \mathrm{C}$; [Found: C, 60.92; H, 7.76; N, 4.01. $\mathrm{C}_{69} \mathrm{H}_{102} \mathrm{~N}_{4} \mathrm{O}_{23}$ requires $\left.\mathrm{C}, 61.14 ; \mathrm{H}, 7.58 ; \mathrm{N}, 4.13 \%\right] ;[\alpha]_{D}^{21}-14.7$ (c 0.74, $\left.\mathrm{CHCl}_{3}\right)$; IR $\left(\mathrm{CDCl}_{3}\right) \vee 3390,2975,2932,2880,1717$, $1685,1526 \mathrm{~cm}^{-1} ;{ }^{1} \mathrm{H}$ NMR $\left(400 \mathrm{MHz}, \mathrm{CDCl}_{3}\right) \delta 8.02$ (br s, $\left.1 \mathrm{H}\right)$, 7.83 (br s, 1H), 7.39 (br s, 1H), 7.38-7.28 (m, 5H), 6.58 (br s, $1 \mathrm{H}), 5.12(\mathrm{~s}, 2 \mathrm{H}), 3.82-3.40(\mathrm{~m}, 16 \mathrm{H}), 3.68(\mathrm{~s}, 3 \mathrm{H}), 2.85(\mathrm{~m}$, $1 \mathrm{H}), 2.55-2.15(\mathrm{~m}, 8 \mathrm{H}), 2.08-1.80(\mathrm{~m}, 15 \mathrm{H}), 1.30-1.10(\mathrm{~m}$, $48 \mathrm{H}) ;{ }^{13} \mathrm{C}$ NMR $\left(100 \mathrm{MHz}, \mathrm{CDCl}_{3}\right) \delta 173.7,171.5,171.1,170.1$, 155.3 , 137.1, 128.2, 127.6, 127.6, 108.5, 108.3, 108.1, 108.1, 107.7, 107.6, 107.5, 79.2, 79.1, 78.9, 78.7, 78.6, 78.5, 78.2, 77.9, 77.5, 66.3, 59.4, 59.0, 58.0, 52.1, 46.3, 46.2, 46.1, 46.0, 41.5, $40.5,40.2,40.1,38.8,37.5,36.6,17.3,17.1,17.0,16.9,16.8$, 16.8, 16.7, 16.6, 16.3; FAB-MS $m / z, 1378\left(\mathrm{M}^{+}+\mathrm{Na}\right)$.

\section{Acknowledgments}

This work was supported in part by a Grant-in-Aid for Young Scientists (A) (25713008) from Japan Society for the Promotion of Science, a Grant-in-Aid for Scientific Research on Innovative Areas 'Advanced Molecular Transformations by Organocatalysts' (26105745) from Ministry of Education, Culture, Sports Science, and Technology, and Special Coordination Funds for Promoting Science and Technology from Japan Science and Technology Agency.

\section{References and notes}

1. (a) Gellman, S. H. Acc. Chem. Res. 1998, 31, 173-180; (b) Cheng, R. P.; Gellman, S. H.; DeGrado, W. F. Chem. Rev. 2001, 101, 3219-3232; (c) Seebach, D.; Matthews, J. L. Chem. Commun. 1997, 2015-2022; (d) Seebach, D.; Beck, A. K.; Bierbaum, D. J. Chem. Biodiv. 2004, 1, 1111-1239; (e) Goodman, C. M.; Choi, S.; Shandler, S.; DeGrado, W. F. Nat. Chem. Biol. 2007, 3, 252-262; (f) Martinek, T. A.; Fulop, F. Chem. Soc. Rev. 2012, 41, 687702; (g) Wu, C. W.; Kirshenbaum, K.; Sanborn, T. J.; Patch, J. A.; Huang, K.; Dill, K. A.; Zuckermann, R. N.; Barron, A. E. J. Am. Chem. Soc. 2003, 125, 13525-13530; (h) Hecht, S.; Huc, I. ed. Foldamers: Structure, Properties, and Applications; Weinheim, Wiley-VCH, 2007; (i) Saraogi, I.; Hamilton, A. D. Chem. Soc. Rev. 2009, 38, 1726-1743; (j) Fischer, L.; Guichard, G. Org. Biomol. Chem. 2010, 8, 3101-3117.

2. (a) Heimgartner, H. Angew. Chem. Int. Ed. 1991, 30, 238-264; (b) Toniolo, C.; Crisma, M.; Formaggio, F.; Valle, G.; Cavicchioni, G.; Precigoux, G.; Aubry, A.; Kamphuis, J. Biopolymers 1993, 33, 1061-1072; (c) Benedetti, E. Biopolymers (Pept. Sci.) 1996, 40, 3-44; (d) Wysong, C. L.; Yokum, T. S.; McLaughlin, M. L.; Hammer, R. P. Chemtech 1997, 26-33; (e) Toniolo, C.; Crisma, M.; Formaggio, F.; Peggion, C. Biopolymers (Pept. Sci.) 2001, 90, 396-419; (f) Tanaka, M. Chem. Pharm. Bull. 2007, 55, 349-358; (g) Crisma, M.; Toniolo, C. Biopolymers (Pept. Sci.) 2015, 104, 46-64.

3. (a) Karle, I. L.; Balaram, P. Biochemistry 1990, 29, 6747-6756; (b) Benedetti, E.; Barone, V.; Bavoso, A.; Di Blasio, B.; Lelj, F.; Pavone, V.; Pedone, C.; Bonora, G. M.; Toniolo, C.; Leplawy, M. T.; Kaczmarek, K.; Redlinski, A. Biopolymers 1988, 27, 357371; (c) Imawaka, N.; Tanaka, M.; Suemune, H. Helv. Chim. Acta 2000, 83, 2823-2835; (d) Tanaka, M.; Nishimura, S.; Oba, M.; Demizu, Y.; Kurihara, M.; Suemune, H. Chem. Eur. J. 2003, 9, 3082-3090.

4. Wolf, W. M.; Stasiak, M.; Leplawy, M. T.; Bianco, A.; Formaggio, F.; Crisma, M.; Toniolo, C. J. Am. Chem. Soc. 1998, 120, 11558-11566, and references cited therein.

5. Oba, M.; Ishikawa, N.; Demizu, Y.; Kurihara, M.; Suemune, H.; Tanaka, M. Eur. J. Org. Chem. 2013, 7679-7682.

6. See supplementary data.

7. (a) Sheldrick, G. M. Program for Crystal Structure Refinement (SHELXL 97): University of Göttingen: Göttingen, 1997; (b) Beurskens, P. T.; Admiraal, G.; Beurskens, G.; Bosman, W. P.; de Gelder, R.; Israel, R.; Smits, J. M. M. The DIRDIF-99 program system, Technical Report of the Crystallography Laboratory, University of Nijmegen: The Netherlands, 1994.

8. CCDC-1052136 (7) and 1052137 (8') contain the supplementary crystallographic data for this paper. These data can be obtained free of charge from The Cambridge Crystallographic Data Centre via: www.ccdc.cam.ac.uk/data_request/cif.

9. In the crystal structure of $\mathrm{dAA}$ peptides, the signs of the $\mathrm{C}$ terminal residue $\phi$ and $\psi$ torsion angles were frequently opposite to those of the preceding residues, but the $(R, R)-\mathrm{Ac}_{6} \mathrm{c}^{35 \mathrm{dBu}}$ homopeptides showed the same $\phi$ and $\psi$ signs of the C-terminal residue as those of the preceding residues. For example, see: (a) Demizu, Y.; Doi, M.; Kurihara, M.; Maruyama, T.; Suemune, H.; Tanaka, M. Chem. Eur. J. 2012, 18, 2430-2439; (b) Oba, M.; Kawabe, N.; Takazaki, H.; Demizu, Y.; Doi, M.; Kurihara, M.; Suemune, H.; Tanaka, M. Tetrahedron 2014, 70, 8900-8907.

10. Pavone, V.; Benedetti, E.; Barone, V.; Di Blasio, B.; Lelj, F.; Pedone, C.; Santini, A.; Crisma, M.; Bonora, G. M.; Toniolo, C. Macromolecules 1988, 21, 2064-2071.

11. Toniolo, C.; Valle, G.; Bonora, G. M.; Crisma, M.; Formaggio, F.; Bavoso, A.; Benedetti, E.; Di Blasio, B.; Pavone, V.; Pedone, C. Biopolymers 1986, 25, 2237-2253.

12. (a) Tanaka, M.; Anan, K.; Demizu, Y.; Kurihara, M.; Doi, M.; Suemune, H. J. Am. Chem. Soc. 2005, 127, 11570-11571; (b) Anan, K.; Demizu, Y.; Oba, M.; Kurihara, M.; Doi, M.; Suemune, H.; Tanaka, M. Helv. Chim. Acta 2012, 95, 1694-1713.

13. (a) Nagano, M.; Doi, M.; Kurihara, M.; Suemune, H.; Tanaka, M. Org. Lett. 2010, 12, 3564-3566; (b) Yamagata, N.; Demizu, Y.; Sato, Y.; Doi, M.; Tanaka, M.; Nagasawa, K.; Okuda, H.; 
Kurihara, M. Tetrahedron Lett. 2011, 52,798-801; (c) Demizu,

Y.; Yamagata, N.; Nagoya, S.; Sato, Y.; Doi, M.; Tanaka, M.;

Nagasawa, K.; Okuda, H.; Kurihara, M. Tetrahedron 2011, 67,

6155-6165. 


\section{Graphical Abstract}

To create your abstract, type over the instructions in the template box below.

Fonts or abstract dimensions should not be changed or altered.

Peptide foldamers composed of six-membered ring $\alpha, \alpha$-disubstituted $\alpha$-amino acids with two changeable chiral acetal moieties

Kazuhiro Tanda, Ryo Eto, Kazuya Kato, Makoto Oba, Atsushi Ueda, Hiroshi Suemune, Mitsunobu Doi, Yosuke Demizu, Masaaki Kurihara, and Masakazu Tanaka

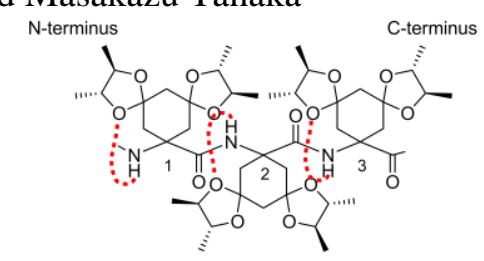

Leave this area blank for abstract info. 